\title{
ANALISIS MISKONSEPSI SISWA DAN CARA MENGATASINYA PADA MATERI BENTUK ALJABAR KELAS VII-C SMP NEGERI 13 MALANG
}

\author{
Rizki Utami \\ (Mahasiswa Program Studi Pendidikan Matematika FKIP Universitas Islam Malang] \\ E-mail: rizki.utami44@yahoo.com
}

\begin{abstract}
Abstrak
Penelitian ini bertujuan untuk mengetahui jenis-jenis miskonsepsi siswa, penyebab miskonsespsi siswa, dan cara mengatasinya pada materi bentuk aljabar kelas VII-C SMP Negeri 13 Malang. Penelitian ini menggunakan pendekatan kualitatif dan jenis penelitian studi kasus. Sumber data dalam penelitian ini adalah siswa kelas VII-C SMP Negeri 13 Malang tahun ajaran 2016/2017 yang telah menempuh materi bentuk aljabar kemudian dipilih tiga siswa untuk dijadikan subjek penelitian. Penelitian ini berlangsung bulan Januari 2017. Teknik pengumpulan data yang digunakan adalah tes, wawancara, dan dokumentasi. Pengecekan keabsahan data dengan triangulasi teknik dan triangulasi sumber. Analisis data melalui tahap reduksi data, penyajian data, dan penarikan kesimpulan. Berdasarkan analisis data dan pembahasan, siswa mengalami miskonsepsi pada bentuk aljabar. Selanjutnya miskonsepsi tersebut diatasi dengan menggunakan strategi analogi dan metode penemuan terbimbing. Cara tersebut disesuaikan dengan miskonsepsi yang dialami masing-masing siswa. Setelah miskonsepsi diatasi, diberikan tes tertulis bentuk aljabar dan wawancara kepada siswa dan hasilnya siswa tidak mengalami miskonsepsi bentuk aljabar lagi.
\end{abstract}

Kata kunci: miskonsepsi, cara mengatasi, bentuk aljabar

\section{PENDAHULUAN}

Pendidikan adalah usaha sadar dan terencana untuk mewujudkan suasana belajar yang baik agar siswa secara aktif mengembangkan potensi yang ada pada dirinya untuk memiliki kekuatan spiritual keagamaan, pengendalian diri, kecerdasan, akhlak mulia, dan keterampilan yang diperlukan dirinya dan masyarakat. Pendidikan seorang anak dapat dimulai dari Taman KanakKanak, Sekolah Dasar, Sekolah Menengah, dan Perguruan Tinggi. Anak berhak mendapatkan pendidikan yang layak untuk masa depannya. Salah satunya adalah anak yang melanjutkan ke Sekolah Menengah Pertama (SMP).

Dalam tahap perkembangan, siswa SMP berada pada periode perkembangan yang sangat pesat dari segala aspek. Perkembangan yang sangat erat kaitannya dengan pembelajaran adalah perkembangan aspek kognitif. Menurut Piaget, periode yang dimulai pada usia 11 tahun dan seterusnya merupakan tahap operasional formal. Tahap operasioanl formal ini merupakan tahap yang kurang lebih sama dengan usia siswa SMP. Sejak tahap ini anak sudah mampu berpikir abstrak. Kemampuan berpikir siswa SMP berkembang sedemikian rupa sehingga dengan mudah dapat membayangkan banyak alternatif pemecahan masalah beserta kemungkinan akibat atau hasilnya. Namun kenyataannya, masih terdapat hambatan yang dialami siswa SMP dalam memecahkan masalah-masalah yang kompleks dan abstrak terutama pada pemahaman konsep yang disampaikan oleh guru. Salah satu hambatan yang terjadi adalah konsep-konsep yang disampaikan oleh guru tidak dapat diterima dengan baik oleh siswa atau sering disebut dengan miskonsepsi. 
Miskonsepsi ini mempunyai dampak negatif kepada siswa. Siswa akan mengalami kesulitan memahami konsep yang disampaikan guru sehingga pengetahuan baru yang akan diterima siswa menjadi terhambat. Miskonsepsi yang dialami setiap siswa dalam satu kelas bisa berlainan satu dengan yang lainnya dengan penyebab yang berbeda-beda pula. Oleh karena itu, peran guru sangatlah penting untuk mengenali miskonsepsi dan penyebab miskonsepsi yang terjadi pada siswa. Selain itu, guru harus dapat menemukan cara untuk mengatasi miskonsepsi tersebut.

Miskonsepsi dapat berbentuk kesalahan konsep awal, kesalahan hubungan yang tidak benar antara konsep-konsep, gagasan atau pandangan yang salah. Novak (dalam Suparno, 2013:4) menyatakan bahwa miskonsepsi merupakan suatu interpretasi konsep-konsep dalam suatu pernyataan yang tidak dapat diterima. Sementara itu, Brown (dalam Suparno, 2013:4) menyatakan bahwa miskonsepsi merupakan penjelasan yang salah dan suatu gagasan yang tidak sesuai dengan pengertian ilmiah yang diterima para ahli.

Menurut Suparno (2013:54), secara umum miskonsepsi dapat disebabkan oleh siswa sendiri, guru yang mengajar, konteks pembelajaran, cara mengajar, dan buku teks. Selain itu, perkembangan kognitif siswa yang tidak sesuai dengan konsep yang dipelajari, penalaran siswa yang terbatas dan salah, kemampuan siswa menangkap dan memahami konsep yang dipelajari, dan minat siswa untuk mempelajari konsep yang diberikan dan diajarkan juga merupakan penyebab terjadinya miskonsepsi. Oleh karena itu, tugas utama guru adalah menyelenggarakan pembelajaran yang baik dan berkualitas sehingga konsep yang disampaikan dapat diterima dengan baik oleh siswa.

Banyak peneliti terdahulu yang mengkaji miskonsepsi siswa pada materi aljabar. Hasil penelusuran dari berbagai literatur dan publikasi penelitian tentang miskonsepsi siswa pada materi aljabar menunjukkan bahwa penelitian-penelitian tersebut masing-masing secara terpisah fokus pada konsepsi variabel, persamaan, pertidaksamaan, atau masalah verbal (soal cerita) dalam aljabar. Para peneliti berupaya untuk mengidentifikasi miskonsepsi berdasarkan salah satu konsep pada materi aljabar dan memberikan penjelasan secara spesifik penyebab miskonsepsi melalui proses penalaran siswa. Namun, masih relatif sedikit penelitian yang dilakukan untuk menganalisis miskonsepsi dan kemampuan siswa yang didasarkan pada gabungan konsep-konsep dalam materi aljabar di tingkat sekolahan (Herutomo dan Saputro, 2014:136).

Matematika merupakan salah satu pelajaran yang banyak menekankan pada konsep, sedangkan konsep itu sendiri adalah suatu hal yang paling mendasar untuk memahami suatu materi. Apabila siswa tidak dapat memahami suatu konsep dengan baik, maka siswa tidak dapat menerima materi pembelajaran dengan benar dan utuh (Irawati, 2014:805).

Bentuk aljabar menempati posisi khusus dalam kurikulum matematika menengah karena banyaknya konsep-konsep yang termuat di dalamnya. Konsep tersebut erat kaitannya dengan masalah di kehidupan sehari-hari yang dijumpai oleh siswa. Penanaman konsep awal untuk materi bentuk aljabar pada kelas VII SMP sangat penting karena masih mendasar.

Tujuan penelitian ini adalah untuk mengetahui jenis-jenis miskonsepsi siswa pada materi bentuk aljabar, penyebab miskonsepsinya, dan cara mengatasi miskonsepsi tersebut. Dengan adanya tujuan penelitian ini akan membantu dalam siswa memahami konsep bentuk aljabar yang disampaikan oleh guru. Sehingga siswa tidak akan mengalami miskonsepsi.

\section{METODE}

Metode yang digunakan pada penelitian ini adalah metode kualitatif, jadi peneliti sendiri yang menjadi instrumen penelitian ini. Jenis penelitiannya yaitu studi kasus. Kasus yang akan diteliti dan dideskripsikan merupakan situasi khusus, yaitu miskonsepsi siswa dan cara mengatasinya pada materi bentuk aljabar. Sumber data dalam penelitian ini adalah siswa kelas VIIC di SMP Negeri 13 Malang tahun ajaran 2016/2017 yang telah menempuh materi bentuk aljabar dan guru matematika kelas VII-C SMP Negeri 13 Malang. Siswa kelas VII-C berjumlah 31 siswa. Dari 31 siswa kemudian akan dipilih 3 siswa untuk dijadikan sebagai subjek. Adapun kriteria 
pemilihan subjek didasarkan pada miskonsepsi yang dialami siswa dan variasi letak miskonsepsi yang dilakukannya. Penentuan subjek dilakukan secara purposive sampling, yaitu teknik pengambilan sampel sumber data dengan pertimbangan tertentu. Pertimbangan tertentu ini, misalnya orang yang dianggap paling tahu tentang apa yang diharapkan sehingga akan memudahkan peneliti menganalisis objek yang akan diteliti. Pada penelitian kualitatif tidak ada sampel acak, tetapi purposive sampling (Moleong, 2013:224).

Teknik pengumpulan data dalam penelitian ini, yaitu dengan menggunakan: (1) tes, metode tes yang dimaksud dalam penelitian ini adalah tes diagnostik yaitu berbentuk soal uraian. Tes diagnostik adalah tes yang digunakan untuk mengetahui kelemahan-kelemahan sehingga dapat dilakukan perlakuan yang tepat (Arikunto dalam Irawati, 2014:2). Tes diagnostik yang dimaksud dalam penelitian ini adalah soal uraian yang akan diujikan kepada siswa agar peneliti dapat mengetahui jenis miskonsepsi siswa, penyebab miskonsepsinya, dan cara mengatasi miskonsepsi tersebut. (2) wawancara adalah percakapan dengan maksud tertentu (Moleong, 2013:186). Percakapan itu dilakukan oleh dua pihak, yaitu pewawancara yang mengajukan pertanyaan dan terwawancara yang memberilan jawaban atas pertanyaan itu. Selain tes diagnostik tadi, peneliti menggunakan pedoman wawancara untuk mengetahui lebih mendalam jenis miskonsepsi dan penyebab miskonsepsi yang dialami siswa. (3) dokumentasi, metode dokumentasi ini digunakan untuk mengumpulkan dokumen yang merupakan catatan peristiwa yang sudah berlalu. Dokumen dimanfaatkan sebagai saksi dari kejadian-kejadian tertentu sebagai bentuk pertanggungjawaban.

Dalam penelitian ini, uji kredibilitas data dilakukan dengan triangulasi. Triangulasi yang digunakan adalah triangulasi sumber dan triangulasi teknik. Triangulasi sumber untuk menguji kredibilitas data dilakukan dengan cara mengecek data yang diperoleh melalui beberapa sumber. Pada pengujian miskonsepsi ini yang menjadi sumber datanya adalah guru dan siswa. Kemudian sumber dideskripsikan. Sedangkan triangulasi teknik dilakukan dengan cara membandingkan data hasil tes tertulis dengan data hasil wawancara sehingga pada akhirnya diperoleh data yang valid yang dapat digunakan dalam analisis data.

Peneliti melakukan analisis selama di lapangan dengan melakukan pengumpulan data yang sedang berlangsung dan setelah pengumpulan data sudah mencukupi dengan melakukan serangkaian tes kepada siswa. Wawancara dilakukan terhadap analisa jawaban dari yang diwawancarai, bila jawaban yang diwawancarai terasa belum memuaskan maka peneliti akan menggali lebih lanjut sehingga diperoleh data yang dianggap kredibel. Analisis data terdiri dari tiga alur kegiatan yang terjadi secara bersamaan, yaitu reduksi data, penyajian data, dan verifikasi data.

\section{HASIL}

Berdasarkan studi pendahuluan yang telah dilakukan, diperoleh data bahwa di kelas VII-C terdapat siswa yang mengalami miskonsepsi pada materi bentuk aljabar. Data tersebut diperoleh dari hasil pengerjaan soal tes berupa uraian bentuk aljabar yang diberikan peneliti kepada siswa kelas VII-C. Setelah pemberian soal tes, ternyata banyaknya siswa yang mengalami miskonsepsi adalah 18 (58\%) dari jumlah keseluruhan 31. Sedangkan siswa yang tidak mengalami miskonsepsi adalah 13 (42\%). Selanjutnya, peneliti memberikan soal tes berupa uraian lagi untuk mengidentifikasi jenis-jenis dan penyebab miskonsepsi yang dialami siswa. Setelah memperoleh hasil tes, peneliti melakukan wawancara kepada ketiga siswa kemudian peneliti menganalisis jenis miskonsepsi yang dialami oleh siswa dan penyebabnya dalam setiap soal yang diberikan. Berikut ini contoh miskonsepsi yang terjadi pada siswa dalam menyelesaikan soal bentuk aljabar.

a. Miskonsepsi yang dialami subjek 1 


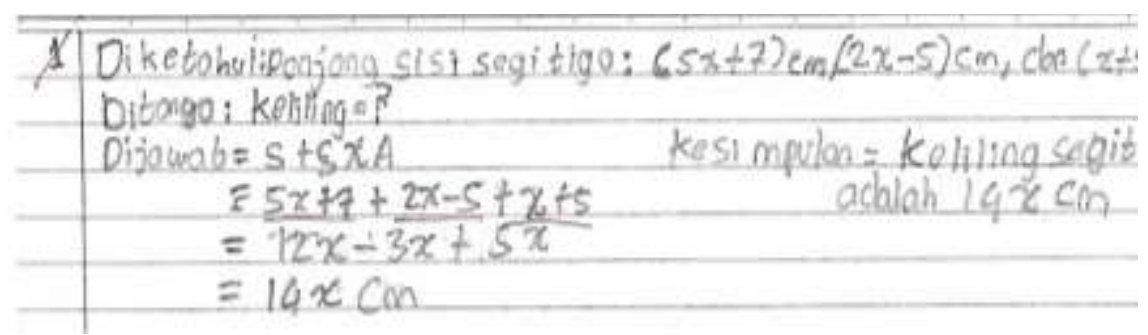

Gambar 1 Hasil Kerja Subjek 1 pada Soal Nomor 1

Berdasarkan gambar subjek 1 mengalami miskonsepsi dalam menjumlahkan dan mengurangkan koefisien dengan konstanta. Subjek menjumlahkan $5 x+7=12 x, 2 x-5=-3 x$. Subjek juga miskonsepsi pada operasi hitung dengan menganggap operasi penjumlahan sebagai operasi perkalian. Subjek mengerjakan $x+5=5 x$.

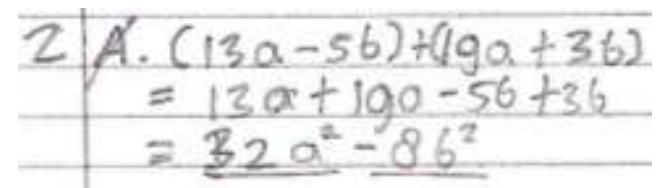

Gambar 2 Hasil Kerja Subjek 1 pada Soal Nomor 2

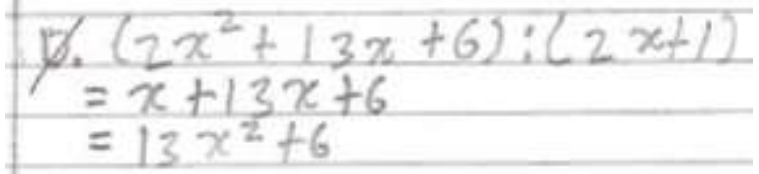

Gambar 3 Hasil Kerja Subjek 1 pada Soal Nomor 2

Selain itu, subjek 1 miskonsepsi pada operasi hitung, subjek menganggap operasi penjumlahan sebagai operasi perkalian. Pada soal nomor $2 \mathrm{a}$, subjek menjawab $13 a+19 a=$ $32 a^{2}$ dan pada soal nomor $2 \mathrm{~d}$, subjek mengerjakan $x+13 x=13 x^{2}$. Pada soal nomor $2 \mathrm{~d}$, siswa juga miskonsepsi pada operasi pembagian dengan menganggap suku yang sejenis dan tidak sejenis dapat diselesaikan dengan menyederhanakannya. Subjek mengerjakan $\left(2 x^{2}+13 x+6\right) \div(2 x+$ 1) langsung menyederhanakan $2 x^{2} \div 2 x=x$ dan $13 x$ tetap serta $6 \div 1=6$. Jadi, jawaban siswa $x+13 x+6$.

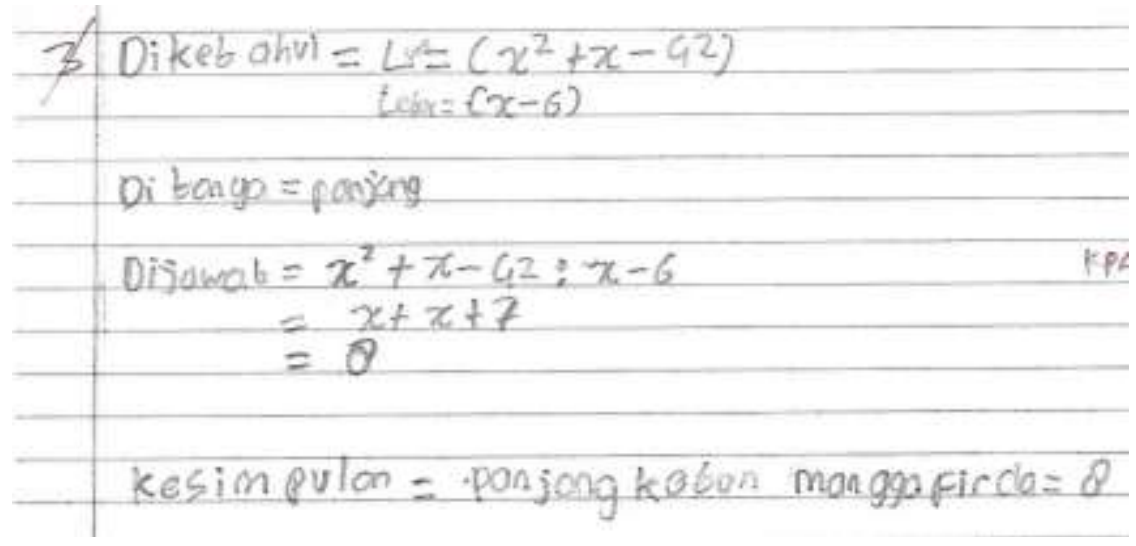

Gambar 4 Hasil Kerja Subjek 1 pada Soal Nomor 3

Subjek 1 juga miskonsepsi pada operasi pembagian. Subjek menganggap suku yang sejenis dan tidak sejenis dapat diselesaikan dengan menyederhanakannya. Subjek mengerjakan $\left(x^{2}+x-\right.$ $42) \div(x-6)$ langsung menyederhanakan $x^{2} \div x=x$ dan $x$ tetap serta $42 \div 6=7$. Jadi, jawaban subjek $x+x+7$.

Dari hasil pekerjaan soal tes dan wawancara yang telah divalidasi dan dianalisis dapat disimpulkan bahwa subjek 1 pada soal nomor 1 mengalami miskonsepsi penggeneralisasian. Pada soal nomor 2a subjek mengalami miskonsepsi notasi, dan pada soal nomor 3 subjek mengalami miskonsepsi pengaplikasian aturan. Hal ini disebabkan karena kemampuan daya ingat siswa yang 
rendah dan perkembangan kognitif siswa yang tidak sesuai dengan bahan ajar yang diminati. Miskonsepsi ini diatasi dengan menggunakan strategi analogi dan metode penemuan terbimbing. Pembelajaran dikaitkan dengan kehidupan nyata siswa yang dapat dilihat oleh indera penglihatan. Sedangkan metode penemuan terbimbing, siswa menemukan sendiri cara untuk menyelesaikan soal bentuk aljabar tetapi masih dalam bimbingan guru.

b. Miskonsepsi yang dialami subjek 2

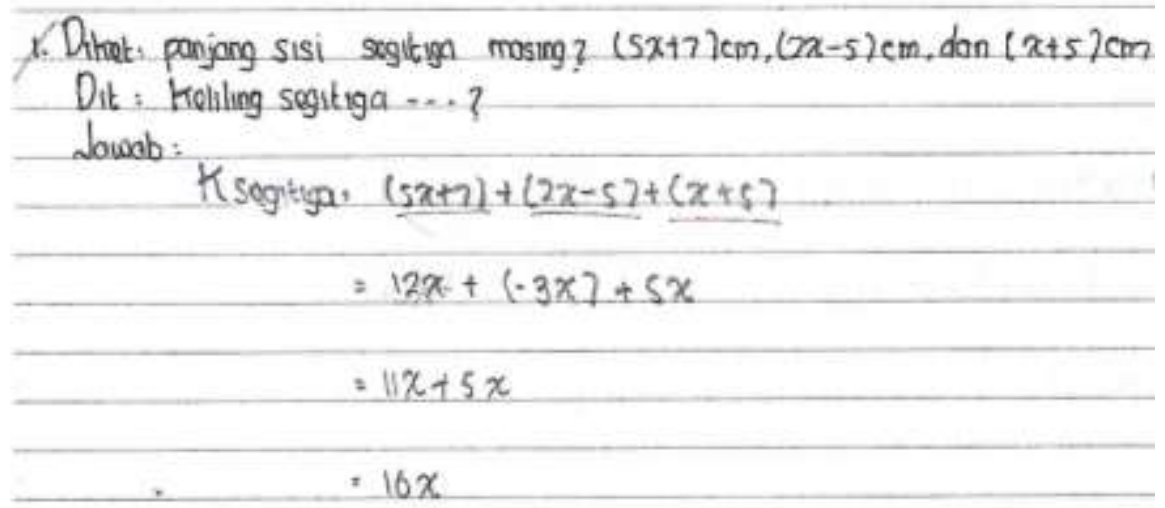

Gambar 5 Hasil Kerja Subjek 2 pada Soal Nomor 1

Subjek 2 miskonsepsi dalam menjumlahkan dan mengurangkan koefisien dengan konstanta. Siswa menjumlahkan $5 x+7=12 x, 2 x-5=-3 x$. Siswa juga miskonsepsi pada operasi hitung, siswa menganggap operasi penjumlahan sebagai operasi perkalian. Siswa mengerjakan $x+5=5 x$.

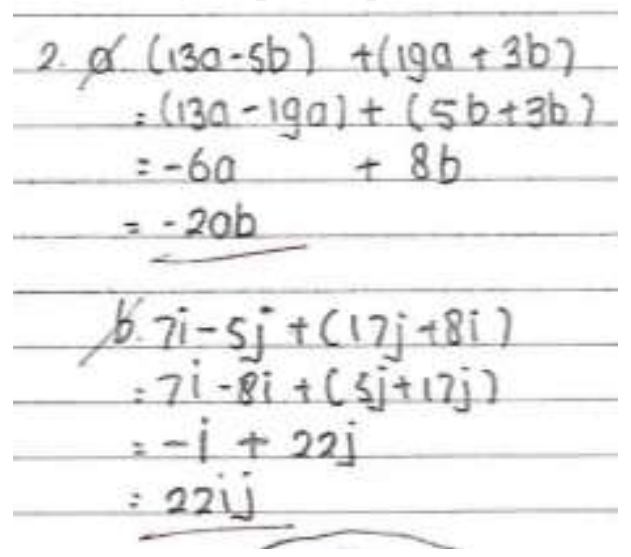

Gambar 6 Hasil Kerja Subjek 2 pada Soal Nomor 2

Subjek 2 juga miskonsepsi dengan mengabaikan keberadaan variabel (huruf). Siswa menganggap variabel yang berbeda dapat dijumlahkan. Siswa menyelesaikan soal dengan menjawab $-6 a+8 b=-2 a b$ dan $-i+22 j=22 i j$. Selain itu, subjek 2 juga mengalami salah konsep pada penggunaan tanda negatif dan tanda positif dalam suku bentuk aljabar. Subjek 2 mengabaikan tanda positif atau negatif didepan suku bentuk aljabar.

Dari hasil pekerjaan soal tes dan wawancara yang telah divalidasi dan dianalisis dapat disimpulkan bahwa subjek 2 pada soal nomor 1 mengalami miskonsepsi penggeneralisasian. Pada soal nomor $2 \mathrm{a}$ dan $2 \mathrm{~b}$ subjek mengalami miskonsepsi pengartian huruf dan miskonsepsi notasi. Hal ini disebabkan karena kemampuan daya ingat siswa yang rendah, minat belajar siswa yang kurang, dan perkembangan kognitif siswa yang tidak sesuai dengan bahan ajar yang diminati. Miskonsepsi ini diatasi dengan menggunakan strategi analogi. Dengan strategi analogi, pembelajaran dikaitkan dengan kehidupan nyata yang dapat dilihat oleh siswa sehingga siswa lebih dapat memahami konsep bentuk aljabar.

c. Miskonsepsi yang dialami subjek 3 


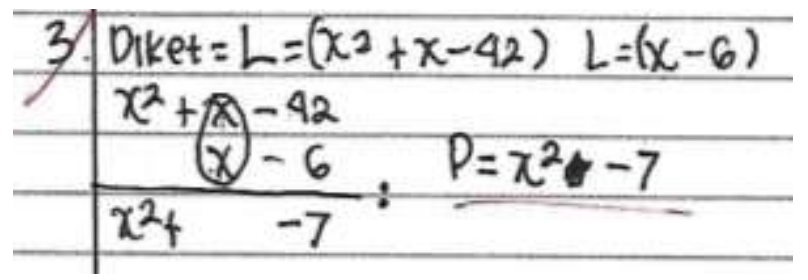

Gambar 7 Hasil Kerja Subjek 3 pada Soal Nomor 3

Subjek 3 miskonsepsi pada operasi pembagian. Siswa menganggap bahwa dalam pembagian suku-suku yang sejenis dapat diselesaikan dengan menyederhanakannya. Siswa mengerjakan $\left(x^{2}+x-42\right) \div(x-6)$ langsung menyederhanakan $x \div x=0$ dan $x^{2}$ tetap serta $42 \div 6=7$ Jadi, jawaban siswa $x^{2}+7$. Siswa juga salah konsep dalam memahami suku sejenis dan suku tak sejenis. Siswa menyebutkan bahwa suku sejenis itu adalah suku yang variabelnya sama. Sedangkan suku tak sejenis adalah suku yang variabelnya tidak sama.

Dari hasil pekerjaan soal tes dan wawancara yang telah divalidasi dan dianalisis dapat disimpulkan bahwa subjek 3 pada soal nomor 3 mengalami miskonsepsi pengaplikasian aturan. Selain itu, dari hasil wawancara subjek 3 juga mengalami miskonsepsi penggeneralisasian karena tidak memahami konsep suku sejenis dan suku tidak sejenis. Hal ini disebabkan karena kemampuan daya ingat siswa yang rendah dan perkembangan kognitif siswa yang tidak sesuai dengan bahan ajar yang diminati. Miskonsepsi ini diatasi dengan menggunakan strategi analogi dan metode penemuan terbimbing.

Berdasarkan hasil tes dan wawancara yang telah dilakukan, jenis miskonsepsi yang dialami siswa pada materi bentuk aljabar dapat dijabarkan sebagai berikut.

a. Miskonsepsi penggeneralisasian

Miskonsepsi penggeneralisasian dapat dilihat dari hasil pekerjaan soal tes siswa nomor 1 dalam menjumlahkan dan mengurangkan koefisien dengan konstanta. Selain itu, siswa juga salah konsep dalam memahami suku sejenis dan suku tak sejenis. Siswa menyebutkan bahwa suku sejenis itu adalah suku yang variabelnya sama. Sedangkan suku tak sejenis adalah suku yang variabelnya tidak sama.

b. Miskonsepsi notasi

Miskonsepsi notasi dapat dilihat dari hasil penyelesaian soal tes siswa soal nomor 2a pada operasi hitungnya, siswa menganggap operasi penjumlahan sebagai operasi perkalian. Selain itu, siswa juga mengalami salah konsep pada penggunaan tanda negatif dan tanda positif dalam suku bentuk aljabar. Siswa mengabaikan tanda positif atau negatif didepan suku bentuk aljabar.

c. Miskonsepsi pengaplikasian aturan

Miskonsepsi kesalahan pengaplikasian aturan dapat dilihat dari hasil pengerjaannya siswa soal nomor 3 dan $2 d$, yaitu pada operasi pembagian. Siswa menganggap suku yang sejenis dan tidak sejenis dapat ditentukan dengan menyederhanakannya.

d. Miskonsepsi pengartian huruf

Miskonsepsi pengartian huruf dapat dilihat dari hasil penyelesaian soal tes subjek 2 nomor 2, yaitu miskonsepsi dalam mengabaikan keberadaan variabel (huruf). Siswa menganggap variabel yang berbeda dapat dijumlahkan.

\section{Pembahasan}

Dalam penelitian ini, peneliti mengidentifikasi jenis-jenis miskonsepsi yang dialami siswa, penyebab miskonsepsi siswa dan cara mengatasi miskonsepsi tersebut kemudian menganalisisnya. Brown (dalam Suparno, 2013:4) menyatakan bahwa miskonsepsi merupakan penjelasan yang salah dan suatu gagasan yang tidak sesuai dengan pengertian ilmiah yang diterima para ahli. Materi yang diujikan adalah materi bentuk aljabar kelas VII SMP dan hanya terbatas pada sub materi operasi bilangan bulat. Penelitian ini menggunakan pendekatan kualitatif dan jenis penelitiannya adalah studi kasus. 
Banyak siswa di kelas VII-C adalah 31 siswa, banyaknya siswa yang mengalami miskonsepsi adalah 18 (58\%). Sedangkan siswa yang tidak mengalami miskonsepsi adalah 13 (42\%). Dari 31 siswa, dipilih tiga subjek penelitian. Pemilihan subjek didasarkan pada miskonsepsi yang dialami siswa serta variasi letak kesalahan konsep yang dilakukannya.

Data dalam penelitian ini diperoleh dari hasil pekerjaan soal tes siswa dan hasil wawancara antara peneliti dengan siswa dan guru matematika siswa. Dari hasil pekerjaan soal tes dan wawancara siswa, dilakukan triangulasi teknik dengan membandingkan kedua hasil tersebut sehingga diperoleh data yang valid. Kemudian data tersebut dianalisis untuk memperoleh kesimpulan yang kredibel.

Jenis miskonsepsi bentuk aljabar yang dialami siswa adalah miskonsepsi penggeneralisasian, miskonsepsi notasi, miskonsepsi pengaplikasian aturan, dan miskonsepsi pengartian huruf. Adapun faktor-faktor yang menyebabkan ketiga subjek mengalami miskonsepsi adalah kemampuan daya ingat siswa yang rendah, perkembangan kognitif siswa yang tidak sesuai dengan bahan ajar yang diminati, dan rendahnya minat belajar siswa pada materi bentuk aljabar. Guru matematika kelas VII-C mengungkapkan bahwa siswa mengalami miskonsepsi karena keterbatasan waktu dalam menyampaikan materi bentuk aljabar dan kurangnya latihan soal bentuk aljabar.

Hasil penelitian adalah siswa mengalami miskonsepsi pada materi bentuk aljabar. Dengan pemberian soal tes bentuk aljabar yang telah divalidasi oleh validator, peneliti sudah dapat mengidentifikasi jenis dan penyebab miskonsepsi yang dialami siswa. Setelah itu, dilakukan wawancara tidak terstruktur kepada siswa dan wawancara semiterstruktur kepada guru untuk mengecek apakah data yang ditemukan sudah valid atau tidak. Ternyata, data tersebut sama. Kemudian miskonsepsi tersebut diatasi dengan menggunakan strategi analogi dan metode penemuan terbimbing, ternyata siswa lebih mudah memahami konsep bentuk aljabar sehingga siswa tidak mengalami miskonsepsi. Hal ini terlihat dari hasil pekerjaan soal tes yang diberikan peneliti kepada siswa dan hasil wawancara antara peneliti dengan siswa.

\section{SIMPULAN DAN SARAN}

Berdasarkan hasil penelitian ini disimpulkan bahwa siswa mengalami miskonsepsi pada bentuk aljabar. jenis-jenis miskonsepsi yang dialami siswa adalah miskonsepsi penggeneralisasian, miskonsepsi notasi, miskonsepsi pengartian huruf, dan miskonsepsi pengaplikasian aturan. Hal ini disebabkan oleh kemampuan daya ingat siswa yang rendah, perkembangan kognitif siswa yang tidak sesuai dengan bahan ajar yang diminatinya, dan minat belajar siswa yang kurang. Miskonsepsi ini diatasi dengan strategi analogi dan metode penemuan terbimbing.

Pada bagian ini dikemukakan saran yang perlu dilakukan guru, siswa, dan peneliti selanjutnya. Untuk guru, hendaknya lebih sering memberikan soal-soal latihan yang memuat pemahaman konsep bentuk aljabar kepada siswa agar siswa lebih memahami konsep bentuk aljabar. Guru juga harus dapat memanfaatkan alokasi waktu yang sudah ditentukan agar proses pembelajaran berjalan dengan baik dan siswa menerima konsep bentuk aljabar yang benar.

Untuk siswa, hendaknya lebih giat belajar dan perbanyak latihan-latihan soal bentuk aljabar agar lebih memahami konsep bentuk aljabar.Untuk peneliti selanjutnya, seharusnya lebih menggunakan waktu dengan sebaik-baiknya dalam melakukan penelitian supaya hasil penelitian dapat maksimal.

\section{DAFTAR RUJUKAN}

Abdurrahman, Mulyono. 2012. Pendidikan bagi Anak Berkesulitan Belajar. Jakarta:Rineka Cipta. 
Abidin, Zainal. 2004. Pentingnya Pemahaman Konseptual dan Prosedural dalam Belajar Matematika. Jurnal Pendidikan dan Pembelajaran. Malang: FKIP Universitas Islam Malang.

Arikunto, Suharsimi, dkk. 2014. Penelitian Tindakan Kelas. Jakarta: Bumi Aksara.

Hamdani. 2011. Stategi Belajar Mengajar. Bandung: Pustaka Setia.

Moleong, Lexy. 2014. Penelitian Kualitatif. Bandung: Remaja Rosdakarya.

Mustangin. 2002. Dasar-dasar Pembelajaran Matematika. Modul tidak diterbitkan. Malang: Universitas Islam Malang.

Riduwan dan Akdon. 2009. Rumus dan Data dalam Aplikasi Statistika. Bandung: Alfabeta.

Sanjaya, W. 2013. Strategi Pembelajaran Berorientasi Standar Proses Pendidikan. Jakarta: Kencana

Sudjana, Nana. 2014. Penilaian Hasil Proses Belajar Mengajar. Bandung: Remaja Rosda Karya.

Sugiyono. 2013. Metode Penelitian Pendidikan Pendekatan Kuantitatif, Kualitatif, dan $R \& D$. Bandung: Alfabeta. 